\title{
Analisis Terhadap Misi Peacebuilding United Nations Transition Administration in East Timor (Untaet)
}

\section{Sugito}

Jurusan IImu Hubungan Internasional, Fakultas IImu Sosial dan IImu Politik, Universitas Muhammadiyah

Yogyakarta

Ringroad Barat Tamantirto, Kasihan, Bantul 55183

Email: gito_20002@yahoo.com

\begin{abstract}
This research aims to determine how UNTAET implemented the mandate as an institution of peace in East Timor, what challenges must be faced in running the mandate. This research based on the literature study methods by using data from journals, books, and sources from the internet. This research shows that UNTAET is success to run the mandate as the institution of peace, especially in the development of security institutions (police, army, judiciary), in the economic (monetary and fiscal), in the politics (government and general election) also in handling humanitarian issues. However, this research also indicates the emergence of some obstacles in implementing UNTAET programs, such as UNTAET institution tends to authoritarian, the lack of local staff in understanding the culture of Timor society, also the lack of support from the International Community. In addition, other challenges come from the lack of Timor society participation in supporting program which designed by UNTAET, also political institution problems and security of former members of Falintil.

Keywords: mass riots, peacebuilding, tripartite talk, referendum

Abstrak

Riset ini bertujuan untuk mengetahui bagaimana UNTAET mengimplimentasikan mandat sebagai lembaga perdamaian di Timor Timur, tantangantantangan apa yang harus dihadapi dalam menjalankan mandat tersebut. Riset didasarkan pada metode studi pustaka dengan menggunakan datadata dari jurnal, buku-buku dan sumber-sumber dari internet. Riset ini menunjukkan bahwa UNTAET telah menjalankan mandat sebagai lembaga perdamaian secara sukses, terutama dalam pengembangan institusi keamanan (polisi, tentara dan lembaga peradilan), dalam bidang ekonomi (sistem moneter dan fiskal), dalam bidang politik (pemerintahan dan pemilihan umum) serta dalam penanganan masalah humanitarian. Meskipun demikian, riset juga menunjukkan munculnya sejumlah hambatan dalam implementasi program UNTAET seperti kecenderungan otoriter dari lembaga UNTAET sendiri, kurangnya pemahaman staf lokal atas kultur masyarakat Timor serta kurangnya dukungan dari masyarakat internasional. Disamping itu, tantangan lain berasal dari kurangnya partisipasi dari masyarakat Timor sendiri dalam mendukung program yang dirancang UNTAET serta problem institusi politik dan keamanan atas mantan anggota Falintil.

Kata kunci: kerusuhan masal, peacebuilding, tripartite talk, referendum
\end{abstract}

\section{PENDAHULUAN}

Perjuangan panjang rakyat Timor Timur untuk merdeka menemukan titik terang ketika Tripartite Talk antara CNRT, Portugal, dan Indonesia dengan fasilitator PBB mengumumkan akan dilaksanakannya referendum pada tangal 30 Agustus 1999. Referendum untuk menentukan apakah Timor Timur merdeka atau tetap bergabung dengan Indonesia menunjukkan hasil bahwa 78,5\% rakyat menghendaki merdeka sedangkan 21,5\% rakyat berkeinginan masih dalam Negara kesatuan RI dengan hak otonom, dan 1,8\% suara tidak sah.

Kondisi keamanan, politik, dan ekonomi 
menjelang dan khususnya pasca referendum mengindikasikan bahwa kemerdekaan Timor Timur bukan menjadi akhir perjuangan rakyat Timor, tetapi justru menjadi awal dari membangun perdamaian yang langgeng di Timor Timur. Dalam masa-masa krisis inilah Timor Timur memerlukan bantuan internasional, khususnya dari PBB untuk membangun perdamaian dan kemerdekaan yang sejati.

Berdasar pada resolusi Dewan Keamanan PBB no 1272 tahun 1999, UNTAET mempunyai mandat untuk menjamin keamanan dan menegakkan hukum dan peraturan di wilayah Timor Timur, menjalankan administrasi pemerintahan yang efektif, membantu pembangunan pelayanan sipil dan social, menjamin koordinasi dan penyaluran bantuan kemanusiaan, dan bantuan-bantuan untuk rehabilitasi dan pembangunan, mendukung capacity-building untuk pemerintahan yang mandiri, dan membantu terbentuknya kondisi untuk pembangunan yang berkelanjutan.

Mandat yang diberikan kepada UNTAET tersebut disertai dengan kewenangan yang sangat besar, sebagaimana tertuang dalam Peraturan No 1 tahun 1999 Tentang Kewenangan Pemerintahan Transisi di Timor Timur. Kewenangan itu meliputi segala urusan legislatif dan ekesutif pemerintah, termasuk urusan administrasi peradilan, yang akan dilaksanakan oleh Administrator Pemerintahan Transisi. Dalam pelaksanaan fungsi-fungsi tersebut, Administrator Pemerintahan Transisi akan berkonsultasi dan bekerjasama secara rutin dengan wakil-wakil rakyat Timor Timur. Administrator Pemerintahan Transisi dapat pula menunjuk atau memberhentikan orangorang untuk melaksanakan fungsi-fungsi tertentu dalam sistim administrasi sipil Timor Timur, termasuk sistem peradilan. Fungsi-fungsi tersebut harus dilaksanakan sesuai dengan hukum dan peraturan yang ada, termasuk juga semua peraturan dan instruksi yang dikeluarkan oleh Administrator Pemerintahan Transisi.

\section{METODE PENELITIAN}

Penelitian ini dilakukan dengan menggunakan metode kajian pustaka melalui berbagai sumber referensi dan bertujuan untuk mengetahui bagaimana pelaksanaan mandate UNTAET tersebut dan hambatan-hambatan apa saja yang ditemui UNTAET dalam melakukan misinya.

\section{HASIL DAN PEMBAHASAN}

KONDISI TIMOR TIMUR PASCA REFERENDUM

Sebagai pemerintahan sementara, UNTAET harus dapat menyelesaikan beberapa permasalahan yang menyangkut isu keamanan, humanitarian, administrasi sipil, demokratisasi, dan restrukturisasi ekonomi (Dobbins, 2005:153-158). Isu keamanan meliputi milisi-milisi yang terorganisasi dan didukung Indonesia, kelompok sayap militer Falintil yang dapat melakukan perlawanan terhadap milisi pro Jakarta sehingga dapat menimbulkan spiral kekerasan. Selain kekerasan dan pengrusakan terhadap fasilitas di Timor Timur, para milisi ini juga melakukan penyerangan diantaranya terhadap tentara penjaga perdamaian di dekat perbatasan dengan Indonesia yang menyebabkan dua tentara mati, penyerangan terhadap anggota perwakilan UNHCR yang sedang berkunjung di Timor Barat yang menyebabkan tiga orang mati pada bulan September 2000.

Kekerasan yang terjadi di Timor Timur juga telah mengakibatkan permasalahan humanitarian berupa pengungsi, sanitasi, dan kesehatan. Kekerasan yang terjadi pasca referendum telah menyebabkan tiga perempat penduduk Timor Timur kehilangan tempat tinggal, lebih dari 200.000 orang dipaksa keluar dari Timor Timur, dan sekitar 100.000 orang tetap tinggal sebagai pengungsi di Indonesia.

Pada sektor pelayanan publik kekerasan pada bulan September telah merusak kantor-kantor pelayanan sipil dan membuat 8000 pegawai negeri sipil pergi ke Indonesia. Hal ini mengakibatkan lumpuhnya pelayaran sipil, sementara itu dalam waktu yang bersamaan pemerintahan Timor Timur belum terbentuk. Ketiadaan pemerintahan ini tentu saja akan berakibat pada permasalahan siapa yang bertugas untuk mengelola bantuan kemanusiaan dan pelayanan sipil.

Kerusuhan masssal selama bulan September juga 
telah mengakibatkan rusaknya $70 \%$ infrastruktur, yang berarti matinya aktivitas ekonomi rakyat. Faktor keamanan juga memberikan andil bagi ketakutan rakyat untuk beraktivitas jual beli dan bercocok tanam. Secara makro, berhentinya aktivitas ekonomi telah mengakibatkan penurunan angka GDP sebesar $30 \%$ pada tahun 1999, inflasi, dan rusaknya sistem fiskal dan moneter pemerintah akibat dari tidak beroperasinya perbankan. Ketika kerusuhan terjadi, perekonomian masyarakat hanya dijalankan dengan sistem tunai.

\section{PEACEBUILDING SEBAGAI KERANGKA BERFIKIR DALAM MEMAHAMI MISI UNTAET}

Kondisi Timor Timur pasca referendum tahun 1999 dapat dikategorikan dalam masyarakat pascakonflik, yang menurut Nicole Ball dapat dilihat dari tiga karakteristik, yaitu institusional, ekonomi dan social, serta keamanan (Nicole, 2001:721). Secara institusional, negara yang mengalami konflik akan ditandai dengan : adanya institusi politik dan administrasi yang lemah, sistem politik yang tidak partisipatoris, kompetisi hebat untuk mencapai kekuasaan pemerintahan, legitimasi pemimpin yang rendah, dan kurangnya konsensus di dalam masyarakat tentang ke mana arah negara harus dibawa. Secara ekonomi dan sosial, masyarakat yang dilanda konflik akan ditandai oleh beberapa hal, yaitu adanya kerusakan dan penurunan infrastruktur ekonomi dan sosial, tingkat hutang luar negeri yang tinggi, anggaran pertahanan yang tinggi, kontraksi ekonomi yang signifikan dan maraknya perekonomian ilegal, kembalinya perekonomian subsisten, lemahnya sumber daya manusia, konflik kepemilikan dan akses terhadap tanah, ketidaksetaraan gender, degradasi kualitas lingkungan, melemahnya struktur sosial, dan adanya indikator-indikator kemiskinan (Nicole, 2001:271).

Sementara, dalam bidang kemanan, masyarakat yang dilanda konflik akan ditandai oleh adanya pembengkakan pasukan militer, adanya oposisi militer dan paramiliter (milisi), banyak beredarnya senjatasenjata kecil, perlunya melakukan assessment ulang terhadap kebutuhan keamanan dan restrukturisasi kekuatan militer, kurangnya transparansi pada permasalahan-permasalahan militer dan akuntabilitas militer terhadap otoritas sipil dan masyarakat, peran politik dari kekuatan militer, dan adanya pelanggaran HAM yang sering dilakukan oleh kekuatan militer (Nicole, 2001:271).

Secara institusional, Timor Timur diwarnai oleh belum dimilikinya pemerintahan, kompetisi yang tinggi diantara kelompok-kelompok masyarakat dalam mencapai kekuasaan, dan belum adanya konsensus dari rakyat tentang arah kehidupan bernegara. Kondisi keamanan ditandai dengan permasalahan milisi, baik yang pro-Jakarta maupun bekas gerilyawan Falintil maupun kelompok-kelompok clandestine lainnya. Sementara itu, kondisi perekonomian Timor Timur mengalami kelumpuhan akibat rusaknya infrastruktur dan sistem perekonomian, kondisi kemiskinan yang akut, dan lemahnya sumber daya manusia.

Dalam proses perdamaian yang panjang, peacebuilding mengarah pada upaya untuk memperbaiki kondisi-kondisi masyarakat seperti tersebut di atas. Peacebuilding sebagai suatu konsep, mendapatkan banyak definisi. Bekas Sekjen PBB, Boutros-Ghali, mendefinisikannya sebagai tindakan untuk mengidentifikasi dan mendukung struktur-struktur yang akan memperkuat dan mempererat perdamaian supaya dapat menghindari terjadinya konflik kembali (An Agenda for Peace, 2nd ed., 1995 :11). Kofi Annan dalam bahasa yang hampir sama medefinisikan peacebuilding sebagai upaya untuk membentuk kondisi yang diperlukan untuk hadirnya perdamaian yang berkelanjutan di masyarakat yang tercabik perang (UN doc no. A/51/4,1999). Dua definisi tersebut, memberikan pemahaman kepada kita, bahwa proses peacebuilding berjalan dalam waktu yang sangat panjang.

Upaya peacebuilding yang panjang dengan fokus pada pemecahan masalah yang menjadi penyebab konflik, dapat dikategorikan dalam dua fase, yaitu transisi dan konsolidasi (Ball,2001:722). Prioritas pada kedua fase tersebut adalah memperkuat institusionalisasi politik, mengkonsolidasikan keamanan internal dan eksternal, dan revitalisasi ekonomi dan sosial, dan 
mempromosikan rekonsiliasi sosial. Tujuan dari fase transisi adalah mendirikan pemerintahan yang legitimate agar dapat melaksanakan tugas-tugas pemerintahan secara efektif dan mampu mengimplementasikan mandat-mandat kunci dari proses reformasi yang dijalankan. Sedangkan pada fase konsolildasi tujuannya adalah memperkuat upayaupaya pada fase transisi.

Misi UNTAET di Timor Timur dapat dikategorikan dalam peacebuilding terutama pada fase transisi. Hal ini sesuai dengan resolusi Dewan Keamanan PBB 1272 tahun 1999 yang berbunyi :

"....Acting under Chapter VII of the Charter of the United Nations,

1. Decides to establish, in accordance with the report of the Secretary-General, a United Nations Transitional Administration in East Timor (UNTAET), which will be endowed with overall responsibility for the administration of East Timor and will be empowered to exercise all legislative and executive authority, including the administration of justice

2. Decides also that the mandate of UNTAET shall consist of the following elements:

a. To provide security and maintain law and order throughout the territory of East Timor;

b. To establish an effective administration;

c. To assist in the development of civil and social services;

d. To ensure the coordination and delivery of humanitarian assistance, rehabilitation and development assistance;

e. To support capacity-building for self-government;

f. To assist in the establishment of conditions for sustainable development; "

Apabila dikaitkan dengan pendapat Nicolle Ball tentang tujuan peacebulding pada masa transisi, maka resolusi itu berarti memberikan mandat kepada UNTAET untuk menjalankan fungsi-fungsi peacebuilding.

Keberhasilan misi peacebuilding pihak ketiga di suatu masyarakat atau negara ditentukan oleh dua hal. Pertama, kemampuan dan kemauan aktor-aktor lokal untuk menyerap dan terlibat dengan program-program bantuan yang diberikan. Supaya tingkat partisipasi rakyat tinggi, maka sebelum melakukan intervensi perlu adanya framing conditions (Alan, 2007: 258), yaitu upaya untuk mempelajari konteks yang lebih spesifik dari masyarakat yang akan dibangun. Framing conditions ini meliputi aspek politik, sosial-ekonomi, dan keamanan. Kedua, adalah kemampuan koordinasi dan kerja sama pihak ketiga dengan stakeholders lainnya yang memiliki perbedaan tujuan, pendekatan, dan budaya. Kerja sama dimaksudkan untuk menjamin bahwa perbedaan mekanisme dan aktivitas yang dilakukan oleh masing-masing stakeholders secara logis berkaitan dan merefleksikan kebutuhan masyarakat setempat.

\section{PELAKSANAAN MANDAT UNTAET DAN PENCAPAIAN HASILNYA}

UNTAET terdiri atas pasukan penjaga perdamaian, Polisi PBB, staff internasional, "sukarelawan PBB, dan staf dari Timor Timur. Beberapa orang lokal digaji oleh UNTAET dan dipekerjakan pada posisi-posisi yang rendah tanpa tanggungjawab administratif. Misi UNTAET mengkombinasikan antara misi penjaga perdamaian dan tanggungjawab Adiministratif pemerintahan, sebagaimana yang diterapkan di Kamboja dan Kosovo. Namun, UNTAET menjadi yang pertama dalam sejarah dimana PBB memiliki tanggungjawab kedaulatan yang absolut tanpa bekerjasama dengan pemerintahan lokal (Neves, 2007:7).

Berdasar pada mandat resolusi PBB no 1272 tahun 1999 dan kondisi yang dihadapi, maka UNTAET melakukan beberpa upaya untuk memperbaiki kondisi Timor Timur. Pada sektor keamanan dan penegakan hukum, salah satu prioritas UNTAET adalah mendirikan angkatan kepolisian baru bagi Timor Timur sebelum kekuasaan diserahkan ke negara baru pada bulan Mei 2002. Misi-misi UNTAET berikutnya di Timor Timur diperintahkan dan diberi wewenang untuk membantu terbentuknya layanan kepolisian yang dapat diandalkan, professional dan adil secara cepat. Upaya tersebut dilakukan melalui rekrutmen prajurit kepolisian baru di Timor Timur yang dimulai 
pada awal tahun 2000, sedangkan pelatihan dasar dimulai pada tanggal 27 Maret 2000 di bawah pengawasan Administrasi Transisi PBB di Timor Timur. Tanggal 10 Agustus 2001, Kepolisian Timor Timur dengan resmi dibentuk bersama-sama dengan Polisi Sipil PBB (CivPol), yang kemudian diubah namanya menjadi Timor-Leste Police Service, sebelum akhirnya memakai nama Polícia Nacional de TimorLeste (PNTL)/Polisi Nasional Timor Timur. Baru pada tanggal 20 Mei 2002, suatu persetujuan ditandatangani yang menentukan garis-garis besar persyaratan dan jadwal bagi CivPol untuk menyerahkan tugas-tugas kepolisian sepenuhnya pada PNTL. Penyerahan tugas-tugas kepolisian bagi distrik terakhir, Dili, berlangsung pada tanggal 10 Desember 2003, dimana PNTL akhirnya menerima tanggung jawab atas tugas-tugas umum kepolisian sehari-hari di seluruh negara tersebut (http://hrw.org/indonesian/ docs/2006/04/20/eastti13229.htm). UNTAET juga membentuk angkatan bersenjata yang disebut Forãas de Defesa de Timor Leste (FDTL). Pasukan ini didominasi oleh unsur Falintil sehingga sering disebut sebagai Falintil-FDTL (F-FDTL).

Dalam rangka menegakkan pemerintahan yang legitimate, UNTAET berhasil melaksanakan Pemilu untuk memilih para wakil rakyat yang di gelar pada tanggal 30 Agustus 2001. Pemilu ini diikuti oleh 16 partai politik dan 16 kandidat independent dengan menjadikan partai Fretilin sebagai pemenangan dengan perolehan suara $57 \%$ atau mendapatkan 55 kursi dari 88 yang diperebutkan. Disusul kemudian oleh Democratic Party (PD) yang memenangkan 7 kursi di parlemen. Dengan perolehan seperti itu, maka Fretilin menjadi pemerintah yang berkuasa dengan mendudukkan Mari Alkatiri sebagai Perdana Menteri dan juga menempatkan 10 orang dalam kabinet pemerintah (Gaglioti, 2001).

Pemulihan infrastruktur di Timor Timur yang hancur akibat kerusuhan selama bulan Agustus hingga Oktober 1999, dilakukan oleh World Bank baik melalui PBB maupun secara bilateral yang didukung oleh beberapa negara. Bantuan sebesar 59 juta dollar Amerika Serikat dikucurkan untuk melakukan perbaikan infrastruktur. Kemajuan signifikan yang dicapai adalah $85 \%$ wilayah Timor Timur telah mendapatkan pasokan listrik.

The Asian Development Bank (ADB) mengucurkan dana 4,5 Juta Dollar AS untuk membangun jalan. Prioritas pembangunannya adalah jalan penghubung wilayah Utara dengan Selatan dan juga dari Dili ke Suai dengan suatu jalan ke Same, dan dari Baucau ke Viqueque (Tibar Document, June 2000). Transportasi udara diperbaiki melalui pembangunan Bandara Dili dan Baucau sebagai bandara internasional dan beberapa bandara regional seperti di Oecussi, Suai, Lospalos, dan Same. Pada sektor air dan sanitasi, tersedia dana 4,5 juta dollar AS untuk tahun 20002001 dari total dana yang dibutuhkan sebesar 40 juta dollar AS dimana 12 sampai 15 juta dollar AS diharapakn berasal dari Trust Fund for East Timor (TFET). Infrastruktur lainnya yang penting adalah telekomunikasi dengan beroperasinya kembali telopon seluler, radio, dan internet. Selain itu juga dibangunnya kembali beberapa gedung public terutama gedung operasional UNTAET, penjara, dan gedung-gedung pemerintahan lainnya (http:// homepage.esoterica.pt/ cdpm/infr02eng.htm).

Keberhasilan UNTAET juga terlihat dari bantuan kemanusian terutama pada masa-masa pasca konflik tahun 1999. Sejak kedatangan UNTAET pada bulan September 1999, lebih dari 75 \% gedung-gedung di Timor Timur rusak dan lebih dari 250.000 orang mengungsi di Timor Barat. UNTAET berhasil bertindak sebagai coordinator untuk memulangkan lebih dari 168.000 orang pengungsi, mendistribusikan 35.000 metrik ton suplai makanan, membuka kembali hamper 750 Sekolah Dasar di 13 distrik, membuka lebih dari 50 fasilitas layanan kesehatan dan 52 mobil klinik di seluruh wilayah Timor Timur, dan mendistribusikan lebih dari 16.000 peralatan pengungsian (UNTAET Humanitarian Assistance and Emergency Rehabilitation Pillar, 2000). Dengan demikian secara kuantitatif nampak adanya keberhasilan UNTAET. 
HAMBATAN-HAMBATAN UNTAET DALAM MELAKSANAKAN MISINYA DI TIMOR TIMUR

Muncul banyak permasalahan ketika UNTAET harus menjalankan misinya di Timor Timur. Beberapa permasalahan yang berkaitan dengan keamanan di wilayah Timor Timur adalah (Ishizuka, 2000) : pertama, kurangnya sumber daya (resources). Kedua, adanya kekuatan keamanan tradisional pada di level lokal maupun nasional (dalam hal ini Falintil). Ketiga, permasalahan konsistensi operasional. Terakhir, hanya sedikit sekali polisi dan sistem peradilan Indonesia yang ada di Timor Timur. Sebagian besar staf militer, polisi, dan peradilan meninggalkan Timor Timur setelah referendum, sedangkan hanya sedikit orangorang Timor Timur asli yang bekerja di institusiinstitusi tersebut. Kepolisian dan sistem peradilan semakin lumpuh dengan rusaknya gedung pengadilan. Oleh karena Indonesia meninggalkan sistem peradilan yang rusak, maka muncul ketidakpercayaan rakyat Timor Timur terhadap proses peradilan (Strohmeyer dalam Dobbins et al, 2001: 155).

Operasi kemanusian UNTAET mendapatkan tantangan beberapa tantangan. Pertama, kondisi sistem kesehatan yang rusak parah. Kedua, permasalahan yang berkaitan dengan banyaknya NGOs yang beroperasi di Timor Timur dengan berbagai macam perbedaan kepentingan (Ishizuka, 2000). Ketiga, kurangnya persediaan logostik dan sumber daya PBB (Ishizuka, 2000). Keempat, permasalahan struktur sosial sebagai penginggalan penjajahan (Ishizuka, 2000). Rehabilitasi di Timor Timur terhambat oleh adanya kelompokkelompok mafia dan gank. Mereka mengganggu proses pembangunan kembali infrastruktur seperti konstruksi, dan industri lokal seperti perikanan, kopi, minyak dan gas bumi.

Dalam hal pembangunan politik dan pemerintahan yang demokratis dan partisipatoris, UNTAET mimiliki kendala partisipasi rakyat Timor Timur yang relative rendah dalam disain maupun implementasi programprogram UNTAET. Ada beberapa sebab kenapa tingkat partisipasi rakyat relative rendah : 1). Elitisme dalam proses pembuatan kebijakan UNTAET, 2). Ketidaktepatan UNTAET dalam Framing Condition atas
Timor Timur sehingga tidak semua komponen masyarakat terwakili bahkan ada kebijakan istimewa bagi eks Falintil, dan 3). Lemahnya sumber daya manusia Timor Timur.

Kegiatan perekonomian rakyat juga tidak tumbuh dengan baik. Selain faktor permodalan, faktor keterampilan berbisnis juga masih minim akibat dari masih kuatnya budaya agraris. Sebagian besar kegiatan perdagangan kecil dan menengah masyarakat - dalam bentuk restaurant, perusahaan sewa mobil, hotel, supermarket untuk ekspatriat - biasanya dimiliki oleh orang asing. Mereka akan menutup usahanya seiring dengan berakhirnya misi UNTAET yang berarti pula pulangnya para staf internasional (http:// www.laohamutuk.org/Bulletin/2005/Aug/ bulletinv6n3.html\#UNMISET_Support_for_Public_Administration).

Besarnya dana bantuan luar negeri yang masuk ke Tmor Timur ternyata juga tidak berdampak pada perbaikan kesejahteraan rakyat. Namun sebaliknya, Dana tersebut justru memunculkan kesenjangan yang sangat besar antara staff internasional dengan penduduk lokal. Pasukan PBB dan para pejabatnya dibayar tunjangan hidup sebesar 100.00 US $\$$ per hari, sebagian besar penduduk Timor Timur berjuang matimatian hanya untuk hidup dari hari ke hari. Sebagian kecil dari mereka yang dapat pekerjaan berpenghasilan rata-rata 6.00 US\$ per minggu (Ward dan Symond, 2002).

Semakin besar operasi PBB di Timor Timur, seharusnya semakin besar pula dana yang dibutuhkan dan digunakan untuk merangsang perkembangan ekonomi lokal. Pada masa-masa sebelumnya, PBB mengimpor banyak barang dan jasa (makanan, air, alatalat cetak, dan sebagainya) dari luar negeri dan digunakan untuk mendukung operasional staf internasionalnya. Hal ini tentu saja tidak memberikan dampak bagi perkembangan pembangunan Timor Timur karena air, alat-alat komunikasi dan barang lainnya selama misi UNTAET hanya diperuntukkan bagi staf internasional bukan untuk rakyat Timor Timur (Ward dan Symond, 2002).

Pada diri UNTAET sendiri mengalami beberapa hambatan yang berkaitan dengan dukungan 
internasional. tersebut bisa berupa dukungan politik, finansial, militer, maupun personel sipil yang diperlukan untuk menjalankan misi-misinya. Dengan tingkat ketergantungan yang tinggi terhadap negaranegara anggotanya, maka efektivitas misi-misi PBB sangat ditentukan oleh tingkat dukungan negara-negara anggotanya terhadap resolusi yang dikeluarkan.

Sejak tahun 1999, dua milyar dollar Amerika dialokasikan bagi Timor Timur sebagai dana bantuan. Lima negara terbesar sebagai donor adalah Portugal, Australia, Amerika Serikat, Jepang, dan Komisi Uni Eropa. Selain itu, UNTAET dan UNMISET memiliki buget tersendiri yang mencapai 1,7 milyar US $\$$, yang berasal dari para anggota PBB. Jika semuanya dijumlah maka bantuan yang mengalir ke Timor Timur selama administrasi UNTAET lebih dari 3 Milyar US\$. Semua bantuan yang diterima adalah grant, proyek atau operasi yang tidak perlu dikembalikan oleh Timor Timur (Neves, 2007: 3).

Secara internal, UNTAET mengalami kegagalan untuk mengendalikan kepentingan para Negara pendonor khususnya Amerika Serikat dan Australia sebagai Negara pendonor terbesar. PBB dalam hal ini, menjadi alat bagi legitimasi politik luar negeri Negaranegara anggotanya dalam rangka mencapai kepentingan nasionalnya. Peran Australia sebagai Negara pendonor terbesar baik secara financial maupun operasi militer tidak terlepas dari kepentingan-kepentingan nasional Australia atas Timor Timur.

Dengan bersandar pada legitimasi misi PBB di Timor Timur, Australia berhasil mencapai kepentingan nasionalnya baik secara politis maupun ekonomis. Secara politik, peran leading Australia dalam misi UNTAET telah berhasil menjadikan Timor Timur sebagai buffer zone sekaligus batu loncatan untuk menancapkan pengaruh politiknya di kawasan asia khususnya Asia Tenggara. Secara ekonomi, Autralia telah berhasil menguasai daerah-daerah kaya minyak di celah Timor. Dua bulan setelah pasukan PBB yang dipimpin Australia melakukan intervensi militer di Timtim, ladang minyak Laminaria-Corallina di Celah Timor mulai berproduksi, November 1999. Hingga tahun lalu Pemerintah Australia mengantongi sedikitnya 1 miliar dollar AS pendapatan dari ladang migas tersebut. Dalam tahun 2003, misalnya, Australia memperoleh 172 juta dollar AS, atau dua kali jumlah APBN Timtim. Ironisnya, Timtim sendiri tidak mendapat bagian meskipun sumur minyak itu di wilayah negaranya.

\section{KESIMPULAN}

Sebagai suatu model intervensi pihak ketiga di suatu wilayah bekas konflik, UNTAET telah menunjukkan sisi-sisi keberhasilan sekaligus beberpa hambatan yang kemudian menyebabkan programprogran UNTAET kurang optimal dalam mempersiapkan kemerdekaan Timor Timur. Keberhasilan sangat nampak pada pembangunan institusi-institusi baik keamanan, politik, sosial, ekonomi, dan kemanusiaan. Namun institusi-institusi tersebut tidak dibarengi dengan kesiapan penduduk lokal untuk menjalankannya. Hal ini disebabkan oleh kurangnya partisipasi rakyat Timor dalam desain dan implementasi program UNTAET.

Selain itu, misi PBB selalu tidak dapat lepas dari kepentingan Negara anggotanya. Hal ini nampak pada misi UNTAET yang sangat tergantung dari donasi Negara-negara anggotanya khususnya dari Australia dan Amerika Serikat. Kepentingan ekonomi politik Australia telah menjadi hambatan dalam menjalankan misi perdamaian UNTAET di Timor Timur.

\section{REFERENSI}

Bryden, Alan. "Shaping the Security Governance Agenda in PostConflict Peacebuilding", http://www.trainingforpeace.org/pubs/ accord/civmil2005.pdf, 13 Januari 2007

Chester A. Crocker, Turbulent Peace : The Challenges of Managing International Conflict, Washington D.C, USIP Press, 2001

Dobbins et al. The UN's Role in Nation-Building : from the Congo to Iraq, Santa Monica : Rand Corporation, 2005

Edward Rees, "UN's failure to integrate Falintil veterans may cause East Timor to fail", http://www.etan.org/et2003/november/23-30/ O0un.htm, 24 Desember 2006

Frank Gaglioti, "Hand-picked cabinet in East Timor", http:// www.wsws.org/articles/2001/oct2001/timo-o03.shtml, 24 Desember 2006

Frank Gaglioti and Mike Head, "UN imposes tight control over East Timor elections", http://www.wsws.org/articles/2001/jul2001/timoj18.shtml, 24 Desember 2006

Guteriano Nicolau S. Neves, "THE PARADOX OF AID IN TIMOR- 
LESTE", dalam http://www.laohamutuk.org/reports/ ParadoxOfAid.pdf, 16 Januari 2007

John Ward dan Peter Symonds, "Keresahan sosial meluap dalam demonstrasi di Timor Timur", http://www.wsws.org/id/2002/ des2002/indo-d11.shtml, 24 Desember 2006

Lambourne, Wendy. "Post-Conflict Peacebuilding : Meeting Human Needs for Justice and Reconciliation", Peace, Conflict and Development - Issue Four, April 2004, dalam http://www.dcaf.ch/ _docs/Yearbook2005/bm_sgpc_ch12.pdf, 13 Januari 2007.

Ponzio, Richard. "Which Strategies and Functions of the United Nations Peacebuilding Commission and Support Office ?" dalam http:// www.vision-forum.org/filedascaricare/articoliUN/Ponzio_EN.pdf, 13 Januari 2007.

Robertson, Kathryn. "Pecebuilding in East Timor", 29 Februari 2000, dalam http://ccic.ca/f/archives/apwg_2000-

02 peacebuilding_in_east_timor.pdf, (12 Januari 2007).

UNTAET Humanitarian Assistance and Emergency Rehabilitation Pillar, "Briefing Notes on the Humanitarian Programme in East Timor", 2 August 2000

, PERATURAN NOMOR 1999/1 TENTANG KEWEWENANGAN PEMERINTAHAN TRANSISI DI TIMOR TIMUR, dalam http://www.un.org/peace/etimor/untaetR/etreg1b.htm, 24 Desember 2006).

- http://www.un.org/peace/etimor/etimor.htm

, Timor Timur: Penyiksaan dan Perlakuan Buruk oleh

Kepolisian , http://hrw.org/indonesian/docs/2006/04/20/ eastti13229. htm, 24 Desember 2006.

, An Agenda for Peace, 2nd ed., 1995. hal 11 